\title{
The increase in albuminuria induced by exercise is not associated with preferential excretion of glycated albumin in Type 1 (insulin-dependent) diabetic patients
}

\author{
P.Cavallo-Perin, A. Chiambretti, V.Calefato, M. Tomalino, R. Urbino, G.Cecchini and G.Pagano \\ Institute of Internal Medicine, University of Turin, Turin, Italy
}

\begin{abstract}
Summary. The increase in urinary albumin excretion induced by acute exercise in Type 1 (insulin-dependent) diabetic patients is associated with the urinary excretion of cationic proteins. To test whether the renal excretion of glycated albumin (more anionic than non-glycated albumin) is affected by exercise, we submitted seven normoalbuminuric (albumin excretion rate $<30 \mathrm{mg} / 24 \mathrm{~h}$ ) Type 1 diabetic patients and six well-matched healthy subjects to an exercise test $(600 \mathrm{kpm} / \mathrm{min}$ for $20 \mathrm{~min})$ on a bicycle ergometer, preceded and followed by a 1-h resting period. The selectivity index (renal clearance of non-glycated/glycated albumin) was not
\end{abstract}

significantly different among the pre-exercise, exercise and post-exercise periods, either in the normal subjects (1.01 \pm 0.03 vs $1.08 \pm 0.06$ vs $1.08 \pm 0.05)$ or in the diabetic patients $(1.25 \pm 0.09$ vs $1.20 \pm 0.07$ vs $1.20 \pm 0.06)$, whereas it was significantly higher $(p<0.05)$ in diabetic patients compared to healthy subjects during pre-exercise. These results are not consistent with the hypothesis that acute exercise may induce a preferential excretion of glycated albumin.

Key words: Renal clearance, exercise, glycated albumin, non-glycated albumin.
Glycation involves both circulating proteins, such as albumin [1], and structural proteins, such as the components of glomerular basement membrane (GBM) [2]. The effect of glycation on the GBM charges has not been completely clarified, though glycated albumin has been reported to be more anionic than unmodified plasma albumin at physiological $\mathrm{pH}[3,4]$. Preferential urinary excretion of glycated albumin in diabetic subjects during normal life conditions (i.e. not during exercise) has been confirmed by some authors $[5,6]$, but refuted by others $[7,8]$. Under shortterm (hours) experimental conditions, it is reasonable to assume that the degree of protein glycation remains constant, since non-enzymatic reactions are very slow and take place during a period of several days or weeks [9]. On the other hand, the increase in albumin excretion rate (AER) induced by exercise in Type 1 (insulin-dependent) diabetic patients is associated with the urinary excretion of cationic proteins [10]. Microalbuminuria in diabetes is thought to be partly dependent on progressive loss of the anionic charges of the GBM as an expression of a reduced proteoglycan turnover [11]. Exercise could affect glomerular permeability and/or tubular reabsorption of proteins conditioning the renal handling of molecules with different charge or conformation.

The aim of the present study is to evaluate the renal excretion of non-glycated and glycated albumin in nor- moalbuminuric diabetic patients during the increased AER induced by acute exercise.

\section{Subjects and methods}

Two groups of subjects were studied. One group consisted of seven Type 1 diabetic patients each receiving three insulin injections per day and with reasonable metabolic control $\left(\mathrm{HbA}_{\mathrm{lc}}<8.5 \%\right.$ during the last year). None had either somatic or autonomic neuropathy, as assessed by standard clinical methods. Retinopathy was assessed on eye-ground examination through dilated pupils: two of seven patients had mild background retinopathy. Patients were selected on the basis of: a) AER $<30 \mathrm{mg} / 24 \mathrm{~h}$ in three 24 -h urine collections; b) absence of post-voiding residual urine in the bladder (echographic evaluation); and c) normal working and physical activity and usual moderately strenuous non-combative sports. The control group consisted of six healthy subjects, matched for age, sex, body mass index, blood pressure and level of physical fitness. None of the subjects (patients or control subjects) had a history of renal disease or first-degree family history of diabetes or hypertension; all had sterile urine and normal values for creatinine clearance; all were normotensive and were receiving no drug other than insulin. Further characteristics of the patients and control subjects are given in Table 1. All the procedures followed were in accordance with the Helsinki Declaration of 1975. All the subjects gave their informed consent to participate in the study.

Both patients and healthy subjects underwent the exercise test at about 10.00 hours. On the morning of the test, waterloading to stable 
Table 1. Characteristics of control subjects and Type 1 (insulindependent) diabetic patients. Mean \pm SEM

\begin{tabular}{lcc}
\hline & $\begin{array}{c}\text { Control } \\
\text { subjects }\end{array}$ & $\begin{array}{c}\text { Diabetic } \\
\text { patients }\end{array}$ \\
\hline Sex (Male/Female) & $3 / 3$ & $4 / 3$ \\
Age (years) & $24 \pm 1$ & $25 \pm 2$ \\
BMI (kg/m $\left.{ }^{2}\right)$ & $21.3 \pm 0.4$ & $20.7 \pm 0.5$ \\
Diabetes duration (years) & - & $6 \pm 1$ \\
HbA $_{1 \mathrm{c}}(\%)$ & $4.9 \pm 0.4$ & $7.8 \pm 0.7$ \\
Plasma albumin $(\mathrm{g} / \mathrm{l})$ & $49.2 \pm 2.3$ & $47.8 \pm 2.6$ \\
Plasma glycated albumin & & \\
$\quad$ (\% total albumin) & $9.8 \pm 0.3$ & $19.2 \pm 0.8$ \\
Systolic blood pressure $(\mathrm{mm} \mathrm{Hg})$ & $117 \pm 4$ & $123 \pm 6$ \\
Diastolic blood pressure $(\mathrm{mm} \mathrm{Hg})$ & $78 \pm 2$ & $81 \pm 4$ \\
Creatinine clearance $\left(\mathrm{ml} / \mathrm{s} \cdot 1.73 \mathrm{~m}^{2}\right)$ & $2.03 \pm 0.19$ & $1.99 \pm 0.30$ \\
\hline
\end{tabular}

Table 2. Albumin and beta-2-microglobulin excretion rate, renal clearance of non-glycated and glycated albumin, and selectivity index (clearance of non-glycated/glycated albumin) in six normal subjects and seven Type 1 (insulin-dependent) diabetic patients during periods of: pre-exercise (A), exercise (B) and post-exercise (C).

\begin{tabular}{|c|c|c|c|}
\hline & & $\begin{array}{l}\text { Control } \\
\text { subjects }\end{array}$ & $\begin{array}{l}\text { Diabetic } \\
\text { patients }\end{array}$ \\
\hline $\begin{array}{l}\text { Albumin } \\
\text { excretion } \\
\text { rate }(\mu \mathrm{g} / \mathrm{min})\end{array}$ & $\begin{array}{l}\mathrm{A} \\
\mathrm{B} \\
\mathrm{C}\end{array}$ & $\begin{array}{l}7.65 \pm 0.55 \\
35.73 \pm 8.16^{\mathrm{a}} \quad(p<0.01) \\
7.72 \pm 1.94 \quad(p<0.01)\end{array}$ & $\begin{array}{c}8.90 \pm 1.87 \\
431.51 \pm 207.19^{2} \\
95.13 \pm 49.78\end{array}$ \\
\hline $\begin{array}{l}\text { Beta-2-micro- } \\
\text { globulin excretion } \\
\text { rate }(\mathrm{ng} / \mathrm{min})\end{array}$ & $\begin{array}{l}\mathrm{A} \\
\mathrm{B} \\
\mathrm{C}\end{array}$ & $\begin{array}{l}42.33 \pm 3.17 \\
40.12 \pm 3.32 \\
40.33 \pm 4.57 \quad(p<0.05)\end{array}$ & $\begin{array}{l}57.71 \pm 9.38 \\
32.85 \pm 5.39^{a} \\
25.28 \pm 8.58\end{array}$ \\
\hline $\begin{array}{l}\text { Clearance of non- } \\
\text { glycated albumin } \\
\left(\mathrm{ml} / \mathrm{min} \cdot 10^{-4}\right)\end{array}$ & $\begin{array}{l}\text { A } \\
\text { B } \\
\text { C }\end{array}$ & $\begin{array}{l}1.60 \pm 0.15 \\
7.37 \pm 1.56^{\mathrm{b}} \quad(p<0.05) \\
1.72 \pm 0.41 \quad(p<0.005)\end{array}$ & $\begin{array}{c}2.09 \pm 0.38 \\
109.29 \pm 52.96^{\mathrm{a}} \\
23.55 \pm 12.28\end{array}$ \\
\hline $\begin{array}{l}\text { Clearance of } \\
\text { glycated albumin } \\
\left(\mathrm{ml} / \mathrm{min} \cdot 10^{-4}\right)\end{array}$ & $\begin{array}{l}\mathrm{A} \\
\mathrm{B} \\
\mathrm{C}\end{array}$ & $\begin{array}{l}1.61 \pm 0.18 \\
6.64 \pm 1.28^{b} \quad(p<0.05) \\
1.58 \pm 0.36 \quad(p<0.005)\end{array}$ & $\begin{array}{l}1.72 \pm 0.32 \\
82.96 \pm 38.41^{\mathrm{a}} \\
18.05 \pm 8.84\end{array}$ \\
\hline Selectivity index & $\begin{array}{l}\text { A } \\
\text { B } \\
\text { C }\end{array}$ & $\begin{array}{l}1.01 \pm 0.03 \quad(p<0.05) \\
1.08 \pm 0.06 \\
1.08 \pm 0.05\end{array}$ & $\begin{array}{l}1.25 \pm 0.09 \\
1.20 \pm 0.07 \\
1.20 \pm 0.06\end{array}$ \\
\hline
\end{tabular}

Mean \pm SEM. One-way ANOVA and Student's $t$-test on $\log _{10}$ scale values: ${ }^{\mathrm{a}} p<0.01$ vs $\mathrm{A}$ and $\mathrm{C} ;{ }^{\mathrm{b}} p<0.05$ vs $\mathrm{A}$ and $p<0.01$ vs $\mathrm{C}$

diuresis [12] was employed to offset the antidiuretic effect of exercise. Blood samples were collected for the measurement of plasma glucose (Glucose Analyzer II, Beckman Instruments, Fullerton, Calif., USA) and HbA (BioRad kit, BioRad Labs, Richmond, Calif., USA). Urine samples were collected over the following three periods, according to the protocol of Viberti et al. [13]: 1) a 1-h preexercise resting period in the sitting position, immediately preceded and followed by a $300 \mathrm{ml}$ drink of tap water; 2) a 20-min exercise period $(600 \mathrm{kpm} / \mathrm{min})$ on a bicycle ergometer; 3$)$ a 1 -h post-exercise period in the sitting position. Systolic blood pressure and blood glucose were monitored every $10 \mathrm{~min}$ during the test, and at the end of each period, respectively. Plasma albumin concentration was measured by autoanalyser on blood samples collected before the test and at the end of each period. The volume of each urine sample was measured and aliquots from each collection were stored at $-80^{\circ} \mathrm{C}$ until determination of albumin (RIA, Albumin kit, Sclavo, RIA Department, Cinisello Balsamo, Milan, Italy) and beta-2-microglobulin (RIA, Beta-2-MG Radioimmunoassay kit, Eiken Chemical Co., Tokyo, Japan). Glycated albumin was measured by HPLC ac- cording to the protocol of Cecchini et al. [14]. Urinary proteins were precipitated by trichloral acetic acid, redissolved, and dialyzed against $0.154 \mathrm{mmol} / \mathrm{l} \mathrm{NaCl}$ to prevent spurious elevation of glycated albumin due to free glucose. A concentration procedure was necessary for samples where the albumin concentration was less than $50 \mu \mathrm{g} / \mathrm{ml}$. Samples were then stored at $-80^{\circ} \mathrm{C}$ until assay. Urinary and plasma albumin separation by affinity chromatography on classic Affi-Gel Blue was confirmed by electrophoresis. Recovery was measured using glycated and non-glycated human serum albumin. After separation from other proteins, albumin was purified by gel chromatography on a Protein Pak 125 column (Waters, Milford, Mass., USA) using a Waters 204 HPLC apparatus (ultraviolet detector set at $280 \mathrm{~nm}$ ). Finally, glycated albumin was separated from the non-glycated by cation-exchange chromatography on an SP5 PW Toyo Soda typical column. HPLC separation gives two peaks representing the glycated and the non-glycated fraction. The amount of the two fractions was measured as a percentage of total internal standard of albumin. The thiobarbituric acid procedure revealed glucose in the glycated fraction only. Glycated and non-glycated albumin were expressed as a percentage of total albumin with an automatic integrator. The standard curve for this assay was linear (range $5-500 \mathrm{mg} / \mathrm{l}$ ) according to the linearity of the ultraviolet detector (total area vs concentration). The inter- and intra-assay plasma and urine variations were 4.2 and $4.7 \%$, and 5.5 and $6.1 \%$ respectively. The correlation between RIA and HPLC determination of total albumin was statistically significant $(r=0.96, p<0.001)$. The ratio between the renal clearance of non-glycated and glycated albumin, as calculated from the plasma and urine measurements, was expressed as the "selectivity index".

The creatinine clearance rate was calculated after creatinine was measured in serum and urine according to an automated kinetic method that used the Jaffe reaction [15].

\section{Statistical analysis}

For statistical calculations the albumin and beta-2-microglobulin rates, and the albumin (non-glycated and glycated) clearances were converted to $\log _{10}$ values because of their skewed distribution. Comparisons between resting, exercise and post-exercise values on $\log _{10}$ scale were performed by the Student's $t$-test when significant differences were found by one-way analysis of variance. All values are expressed as means $\pm \mathrm{S} E M$.

\section{Results}

Mean values of albumin and beta-2-microglobulin excretion rate, of renal clearance of non-glycated and glycated albumin, and of selectivity index are reported in Table 2. During exercise, the increase in AER on basal values was significantly higher in diabetic patients than in control subjects $(p<0.01)$. During the post-exercise period, AER values were similar to the pre-exercise levels in control subjects, whereas they were significantly higher $(p<0.05)$ than pre-exercise levels in diabetic patients. Urinary beta2-microglobulin excretion rate did not increase from the pre-exercise to exercise and post-exercise period in either control subjects or in diabetic patients.

The mean value of the selectivity index was significantly higher in diabetic patients than in control subjects only during the pre-exercise period $(p<0.05)$, but it did not change significantly from the pre-exercise, exercise and post-exercise period in either group of subjects.

Since the diabetic group was heterogeneous in its response to exercise (large standard errors), individual 
Table 3. Individual values of albumin excretion rate, renal clearance of non-glycated and glycated albumin in Type 1 (insulin-dependent) diabetic patients during periods of pre-exercise (A), exercise (B) and post-exercise (C)

\begin{tabular}{|c|c|c|c|c|c|c|c|c|c|}
\hline \multirow[t]{2}{*}{$\begin{array}{l}\mathrm{Pa}- \\
\text { tient }\end{array}$} & \multicolumn{3}{|c|}{$\begin{array}{l}\text { Albumin excretion } \\
\text { rate } \\
(\mu \mathrm{g} / \mathrm{min})\end{array}$} & \multicolumn{3}{|c|}{$\begin{array}{l}\text { Clearance of non- } \\
\text { glycated albumin } \\
\left(\mathrm{ml} / \mathrm{min} \cdot 10^{-4}\right)\end{array}$} & \multicolumn{3}{|c|}{$\begin{array}{l}\text { Clearance of gly- } \\
\text { cated albumin } \\
\left(\mathrm{ml} / \mathrm{min} \cdot 10^{-4}\right)\end{array}$} \\
\hline & $\bar{A}$ & $B$ & $\mathrm{C}$ & $\mathrm{A}$ & B & $\mathrm{C}$ & A & B & $\mathrm{C}$ \\
\hline 1 & 4.70 & 120.01 & 22.83 & 1.08 & 27.30 & 5.34 & 1.04 & 27.12 & 5.13 \\
\hline 2 & 17.21 & 20.49 & 20.97 & 3.03 & 3.79 & 3.53 & 2.65 & 3.31 & 3.13 \\
\hline 3 & 7.62 & 20.00 & 23.06 & 1.88 & 5.10 & 5.55 & 2.00 & 5.35 & 5.94 \\
\hline$T$ & 10.39 & 292.97 & 58.35 & 2.70 & 76.15 & 14.99 & 1.91 & 55.05 & 11.33 \\
\hline 5 & 7.38 & 1594.00 & 19.89 & 1.91 & 405.50 & 4.83 & 1.23 & 295.80 & 3.64 \\
\hline o & 12.55 & 448.02 & 145.01 & 3.35 & 120.24 & 39.17 & 2.74 & 97.24 & 30.90 \\
\hline 7 & 2.45 & 525.01 & 374.99 & 0.65 & 127.29 & 91.44 & 0.45 & 96.84 & 66.29 \\
\hline
\end{tabular}

values of the AER and the clearances of non-glycated and glycated albumin of diabetic patients are reported in Table 3.

There was a positive correlation between $\mathrm{HbA}_{1 \mathrm{c}}$ and plasma glycated albumin concentration $(r=0.791$, $p<0.001$ ). There was no significant correlation between the selectivity index and $\mathrm{HbA}_{1 \mathrm{c}}$ or plasma glycated albumin values.

In diabetic patients, mean values of plasma glucose in the three periods of observation were: $7.1 \pm 1.1,6.3 \pm 0.9$ and $5.9 \pm 0.4 \mathrm{mmol} / \mathrm{l}$ respectively. Systolic blood pressure during exercise did not rise in the diabetic patients (from $122 \pm 5$ to $151 \pm 6 \mathrm{~mm} \mathrm{Hg}$ ) more than in the control subjects (from $118 \pm 4$ to $153 \pm 3 \mathrm{~mm} \mathrm{Hg}$ ).

\section{Discussion}

During exercise, the AER values increased by about fivefold compared to the basal values in control subjects and about 45 fold compared to the basal values in diabetic patients. The lack of increase in beta-2-microglobulin excretion suggests that the increase in AER induced by exercise is mainly due to increased glomerular permeability [13], even though a reduced tubular reabsorption of albumin cannot be excluded.

The large standard errors of the AER and the clearances of non-glycated and glycated albumin indicate that the diabetic group is heterogeneous in its response to exercise. Such heterogeneity has been previously reported by other authors [13] under experimental conditions similar to ours, and could depend on different degrees of initial glomerular abnormalities unmasked by exercise, possibly in relation to the individual's susceptibility to diabetic nephropathy [2].

The mean value of the renal clearances of non-glycated and glycated albumin during exercise was about four times that of the pre-exercise period in normal subjects, and about 50 times in the diabetic patients. However, the increase in the clearance of these two proteins during exercise was parallel, resulting in a mean selectivity index not significantly different from that of the pre-exercise period in both groups of subjects. This finding has, to our knowledge, not yet been reported and suggests that the ability of the kidney to differentiate between non-gly- cated and glycated albumin is not modified by exercise. One explanation would be that albumins with relatively close isoelectric point values are not handled significantly differently by the barrier or that the difference in the charge of the two albumins is offset by the difference in their conformation [16]. However, since clearance values give no information about the extent of glomerular filtration or tubular reabsorption defects, the possibility that the difference in the charge of the two albumins is offset by a difference in tubular reabsorption must also be considered.

Even though the renal charge selectivity is apparently unaffected by exercise, it is altered in normoalbuminuric diabetic patients under resting conditions (pre-exercise). The renal clearance of non-glycated albumin was quite similar to that of glycated albumin in normal subjects resulting in a mean selectivity index of about 1 . In contrast, diabetic patients showed a $30 \%$ higher clearance of nonglycated albumin combined with a slightly higher clearance of glycated albumin, resulting in a mean selectivity index significantly higher than in normal subjects. This finding indicates that in normoalbuminuric diabetic patients the renal excretion of glycated albumin is relatively lower than that of non-glycated albumin, as previously documented by Kverneland et al. [7, 8] on 24-h urine collection during normal physical activity. On the other hand, our results and those of Kverneland et al. disagree with the preferential urinary excretion of glycated proteins reported by others $[5,6]$ using a method considered as poorly specific for glycated albumin [17].

The mechanism behind the increased selectivity index in normoalbuminuric diabetic patients cannot be evaluated under our experimental conditions, but the results of the present study are not consistent with the possibility that physical exercise may induce a preferential excretion of glycated albumin.

Acknowledgements. This work was partially supported by grants from Ministero Publica Istruzione (Italy), quota $60 \%$ and $40 \%$ 1989, and from C.N. R. grant No.89.02721.04.

\section{References}

1. Kennedy L, Mehl TD, Riley WJ, Merimee TJ (1981) Non-enzymatically glycosylated serum proteins in diabetes mellitus: an index of short-term glycaemia. Diabetologia 21: 94-98

2. Krempf M, Marre M (1987) La microalbuminurie chez les diabetiques. I - Definition, interet et physiopathologie. Diab Metab 13: 225-231

3. Day JF, Thorpe SR, Baynes JW (1979) Nonenzymatically glycosylated albumin. J Biol Chem 254:595-597

4. Ghiggeri GM, Candiano G, Delfino G, Queirolo C (1985) Electrical charge of serum and urinary albumin in normal and diabetic humans. Kidney Int 28: 168-177

5. Ghiggeri GM, Candiano G, Delfino G, Bianchini F, Queirolo C (1984) Glycosylated albumin and diabetic microalbuminuria: demonstration of an altered renal handling. Kidney Int 25: 565570

6. Gragnoli G, Signorini AM, Tanganelli I (1984) Non-enzymatic glycosylation of urinary proteins in Type 1 (insulin-dependent) diabetes: correlation with metabolic control and the degree of proteinuria. Diabetologia 26:411-414 
7. Kverneland A, Feldt-Rasmussen B, Vidal P et al. (1986) Evidence of changes in renal charge selectivity in patients with Type 1 (insulin-dependent) diabetes mellitus. Diabetologia 29: 634-639

8. Kverneland A, Welinder B, Feldt-Rasmussen B, Deckert T (1988) Improved metabolic control does not alter the chargedependent glomerular filtration of albumin in uncomplicated Type 1 (insulin-dependent) diabetes. Diabetologia 31: 708-710

9. Brownlee M, Vlassara H, Cerami A (1984) Nonenzymatic glycosylation and the pathogenesis of diabetic complications. Ann Int Med 101: 527-537

10. Tetta C, Cavallo-Perin P, Roggero $S$ et al. (1988) Exercise-induced microalbuminuria in diabetes is associated with the urinary excretion of cationic proteins. Clin Nephrol 30: 270-275

11. Wahl P, Deppermann D, Hasslacher C (1982) Biochemistry of glomerular basement membrane of the normal and diabetic human. Kidney Int 21: 744-749

12. Viberti GC, Mogensen CE, Keen H, Jacobsen FK, Jarret RJ, Christensen CK (1982) Urinary excretion of albumin in normal man: the effect of water loading. Scand J Clin Lab Invest 42: 147151

13. Viberti G, Jarret RJ, McCartney M, Keen H (1978) Increased glomerular permeability to albumin induced by exercise in diabetic subjects. Diabetologia 14: 293-300
14. Cecchini G, Calefato V, Chiambretti A, Cavallo M, Dianzani MU, Vitelli A (1986) Glycosylated serum albumin: high performance liquid chromatography (HPLC) evaluation in normal and diabetic patients. IRCS Med Sci 14: 1027-1028

15. Fabini DL, Ertingshausen G (1971) Automated reaction-rate method for determination of serum creatinine with the CentrifiChem. Clin Chem 17:696-700

16. Shaklai N, Garlick RL, Bunn HF (1984) Nonenzymatic glycosylation of human serum albumin alters its conformation and function. J Biol Chem 259: 3812-3817

17. Schleicher E, Wieland OH (1981) Specific quantitation by HPLC of protein (Lysine) bound glucose in human serum albumin and other glycosylated proteins. J Clin Chem Clin Biochem 19: 81-87

Received: 29 April 1991

and in revised form: 12 August 1991

Dr. P. Cavallo-Perin

Instituto di Medicina Interna

Corso Polonia 14

I-10126 Torino

Italy 